\title{
Nitro blue tetrazolium test in children with kwashiorkor with a comment on the use of latex particles in the test
}

\author{
SAMI SHOUSHA ${ }^{1}$ AND KARIM KAMEL \\ From the Research Haematology Division, U.S. Naval Medical Research Unit No. 3, Cairo, Egypt
}

SYNOPSIS The nitro blue tetrazolium test was applied on neutrophils from children with kwashiorkoru and from control children. The percentage of formazan cells formed in the kwashiorkor patients was. significantly less than in the control group in spite of the presence of associated infections in the former. A direct correlation exists between the percentage of formazan cell formation and totalo serum proteins, albumin, and haemoglobin. These findings may reflect a decreased bactericidal $\rightarrow$ activity of neutrophils in kwashiorkor. The use of latex particles is an unnecessary technical refine- $\subseteq$ ment of the test.

Children with kwashiorkor almost invariably suffer from concomitant infections (Trowell, 1949; Williams, 1953; Scrimshaw, Wilson, and Bressani, 1960; Phillips and Wharton, 1968) for which several factors have been blamed. These include decreased antibody production (Brown and Katz, 1965; Scrimshaw, Taylor and Gordon, 1968) and reduced levels of immunoglobulins (Brown and Katz, 1965; Aref, Badr El Din, Hassan, and Araby, 1970), diminished tissue resistance and lowered phagocytic activity of the polymorphonuclear neutrophil leucocytes (Scrimshaw et al, 1959 and 1968).

We have applied the nitro blue tetrazolium test for the study of the integrity of the polymorphonuclear neutrophil leucocytes in children with kwashiorkor as an index of their defence mechanism. This test was introduced by Baehner and Nathan in 1966 for the study of the polymorphonuclear neutrophil leucocytes from children with chronic granulomatous disease who die early in life from repeated infections. In this disease, the capacity of polymorphonuclear neutrophil leucocytes to reduce the nitro blue tetrazolium salt (Baehner and Nathan, 1966 and 1967) and to form formazan cells (Gifford and Malawista, 1970) was found to be greatly diminished.

IOn leave to NAMRU-3 for M.D. study from Mansourah Faculty of Medicine. Study supervised by Professor K. Kamel Ahmad. Present address: Department of Pathology, Mansourah Faculty of Medicine, Gairo University, Mansourah, Egypt.

'Requests for reprints should be addressed to Dr. Karim Kamel, US Naval Medical Research Unit No. 3 (NAMRU-3), c/o Spanish Embassy, US Interests Sections, Cairo, Egypt.

Received for publication 19 October 1971.
Moreover, these leucocytes were incapable of killingס certain bacteria (Holmes, Quie, Windhorst, and Good, 1966; Quie, White, Holmes, and Good, 1967) and a correlation was drawn between the power of the cellsa to reduce nitro blue tetrazolium and their bactericidalo activity (Windhorst, Holmes, and Good, 1967).

\section{Cases}

Fourteen children with kwashiorkor at the height of: the disease, aged between 1 and 3 years, were studied. All of them had diarrhoea and some had? also other infections, eg, bronchitis, broncho-3 pneumonia, otitis media, and skin infections. Thirteen well nourished children, free from infections and of the same age group, were studied for comparison.

\section{Methods}

The following laboratory determinations werê carried out: total serum proteins and albumin or haemoglobin and haematocrit values, and totai ${ }^{\circ}$ leucocyte counts. The nitro blue tetrazolium test wast done by the method of Gifford and Malawista (1970) for all the cases without incubation with latexo particles and for some of them (11 kwashiorkor and 12 control) with such incubation.

\section{Results}

Table I shows the clinical and laboratory data of the individuals studied. The mean weights of the kwashi orkor and control children compared to the Harvard 


\begin{tabular}{|c|c|c|c|c|c|c|c|c|}
\hline & Case No. & $\begin{array}{l}\text { Age } \\
\text { (mth) }\end{array}$ & $\begin{array}{l}\text { Percentage of } \\
\text { Weight to } \\
\text { Normal }\end{array}$ & $\begin{array}{l}\text { Total Serum } \\
\text { Proteins } \\
(\mathrm{g} / 100 \mathrm{ml})\end{array}$ & $\begin{array}{l}\text { Serum } \\
\text { Albumin } \\
(\mathrm{g} / 100 \mathrm{ml})\end{array}$ & $\begin{array}{l}\text { Haemoglobin } \\
(\mathrm{g} / 100 \mathrm{ml})\end{array}$ & $\begin{array}{l}\text { Haematocrit } \\
(\%)\end{array}$ & $\begin{array}{l}\text { Total } \\
\text { Leucocyte } \\
\text { Count } \\
(\text { cells/c mm) }\end{array}$ \\
\hline $\begin{array}{l}\text { Kwashiorkor } \\
\text { Control }\end{array}$ & $\begin{array}{l}14 \\
13\end{array}$ & $\begin{array}{l}24 \pm 7 \\
27 \pm 9\end{array}$ & $\begin{array}{l}65 \pm 13 \\
93 \pm 11\end{array}$ & $\begin{array}{l}4 \cdot 6 \pm 1 \cdot 1 \\
7 \cdot 1 \pm 0 \cdot 5\end{array}$ & $\begin{array}{l}2.0 \pm 0.6 \\
3.8 \pm 0.5\end{array}$ & $\begin{array}{l}7 \cdot 2 \pm 1 \cdot 2 \\
11 \cdot 2 \pm 0.7\end{array}$ & $\begin{array}{l}23 \cdot 1 \pm 5 \cdot 0 \\
32 \cdot 5 \pm 2 \cdot 4\end{array}$ & $\begin{array}{l}11746 \pm 8200 \\
11965 \pm 3412\end{array}$ \\
\hline
\end{tabular}

Table I Clinical and laboratory data of kwashiorkor and control children (mean $\pm S D$ )

standard (Nelson, 1960) were 65 and $93 \%$ respectively. The kwashiorkor patients manifested various degrees of hypoproteinaemia, hypoalbuminaemia, and anaemia. Their mean total leucocytic count was within the normal range.

Table II gives the results of the nitro blue tetrazolium test. Particulars of these data are illustrated

\begin{tabular}{|c|c|c|c|c|}
\hline & \multicolumn{4}{|c|}{ Formazan Cells (\%) } \\
\hline & \multicolumn{2}{|c|}{ Without Latex } & \multicolumn{2}{|c|}{ With Latex } \\
\hline & $\begin{array}{l}\text { No. of } \\
\text { Cases }\end{array}$ & Average $\pm S D$ & $\begin{array}{l}\text { No. of } \\
\text { Cases }\end{array}$ & Average $\pm S D$ \\
\hline $\begin{array}{l}\text { Kwashiorkor } \\
\text { Control }\end{array}$ & $\begin{array}{l}14 \\
13\end{array}$ & $\begin{array}{l}48 \cdot 6 \pm 20 \cdot 4 \\
88 \cdot 9 \pm 11 \cdot 7\end{array}$ & $\begin{array}{l}11 \\
12\end{array}$ & $\begin{array}{l}58.6 \pm 20.0 \\
96.7 \pm 3.4\end{array}$ \\
\hline
\end{tabular}

Table II Results of nitro blue tetrazolium test on kwashiorkor and control children $P^{1}$

${ }^{1}$ Significance of difference between the mean results for kwashiorkor and control children is $<0.001$ in both tests.

in Figure 1. Without latex $88.9 \%$ of polymorphonuclear neutrophil leucocytes from the control group and $48.6 \%$ from children with kwashiorkor were transformed into formazan cells. These are highly significant different results $(P<0.001)$. Upon adding latex particles to the test media, these percentages increased to $96.7 \%$ and $58.6 \%$ respectively $(\mathrm{P}<0.001$ with a very high direct correlation between the two procedures $(r=0.95)$.

A direct correlation exists between the percentage of formazan cell formation and the amount of total serum proteins $(r=0.71$ when the test was carried out without latex and 0.69 when done with it), albumin ( $r=0.78$ and 0.76 respectively), and haemoglobin $(r=0.67$ and 0.65$)$. In all cases $P$ was $<0.001$. All the correlations are thus higher when the test was done without latex and these are illustrated in Figure 2. There is no correlation between the total leucocyte counts and formazan cell formation.

\section{Discussion}

The percentage of formazan cell transformation in our laboratory is higher than that of Gifford and Malawista (1970) $(88.9-96.7$ versus $40 \%)$ for the

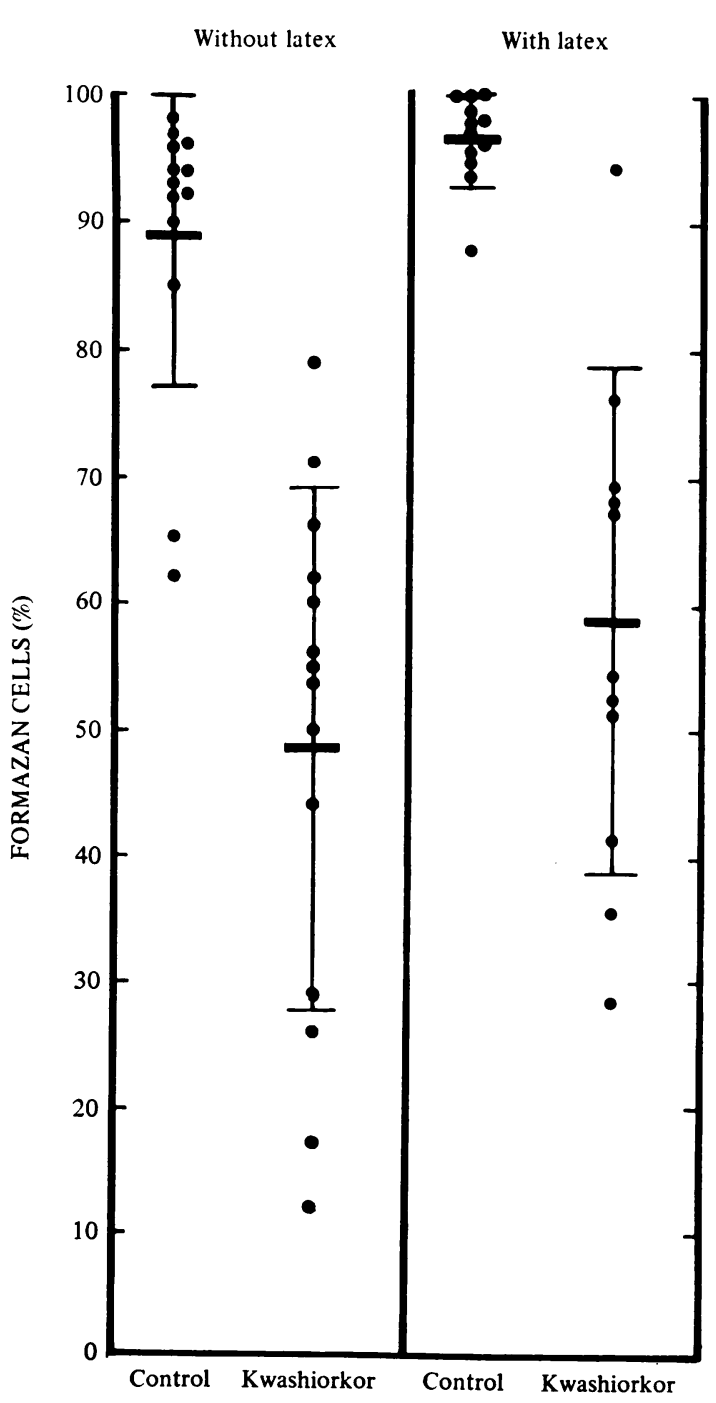

Fig. 1 Formazan cell formation in neutrophils of kwashiorkor and control children in the test as applied without and with latex particle incubation. 


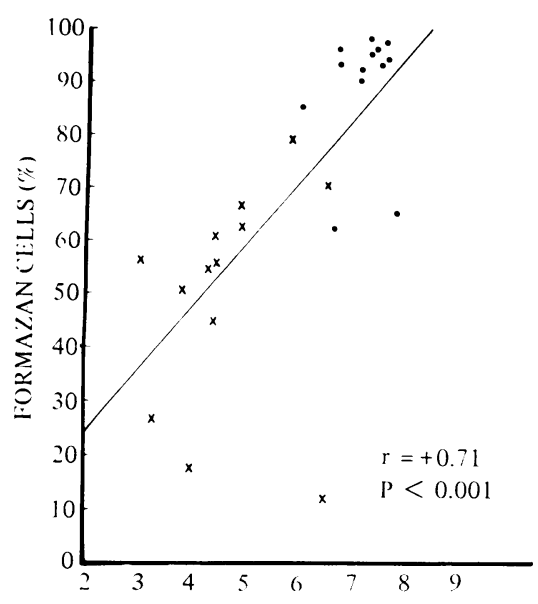

TOTAL SERUM PROTFINS $(\mathrm{g} / 100 \mathrm{ml})$

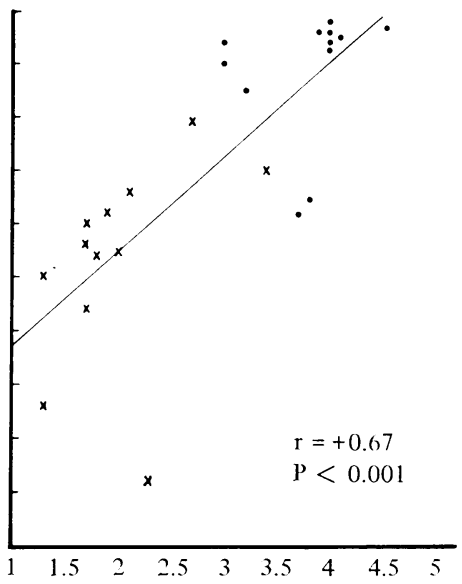

SERUM ALBUMIN $(\mathrm{g} / 100 \mathrm{ml})$

x Kwashiorkor

- Control

Fig. 2 Correlations between formazan cell formation and total serum proteins, albumin, and haemoglobin by neutrophils of kwashiorkor and control children.

normal control children. Our value is comparable, however, to that of Mandell and Hook (1969).

The stimulating effect of phagocytosis in our study, using latex particles, conforms with previous reported results (Baehner and Nathan, 1967 and 1968). However, as others have pointed (Gifford and Malawista, 1970) this effect seems an unnecessary technical refinement in view of the high correlation between the two procedures.

The reduction of nitro blue tetrazolium by normal polymorphonuclear neutrophil leucocytes depends upon the adequate activation of an enzyme in the phagocytic vacuole (Nathan, Baehner, and Weaver, 1969). The enzyme that is directly or indirectly responsible is thought to be reduced nicotinamide adenine dinucleotide (NADH) oxidase (Baehner and Nathan, 1967; Nathan et al, 1969) which plays a key role in the hexose monophosphate pathway from which the polymorphonuclear neutrophil leucocytes obtain the necessary energy for their bactericidal capacity (Selvaraj and Sbarra, 1966). The activity of that enzyme system and/or its release is thus significantly reduced in kwashiorkor as shown by the decreased ability of the cells in this condition to form formazan cells in spite of associated infections known to enhance this phenomenon (Park, Fikrig, and Smithwick, 1968). These findings indicate reduced bactericidal activity of polymorphonuclear neutrophil leucocytes in kwashiorkor.

The influence of malnutrition upon results of the nitro blue tetrazolium test in kwashiorkor is sug- gested by the direct relationship between the abilityo of polymorphonuclear neutrophil leucocytes to form formazan cells and upon total serum proteins $\overline{0}$ albumin, and haemoglobin levels. The use of thiso simple test may find its wide application in the assessment of the cells' defence mechanism in thoseo areas where malnutrition is prevalent in its different ${ }^{\beta}$ forms. It is possible that, in the future, the use of leucocyte transfusions could be gratifying whenever deemed advisable in these cases.

The opinions and assertions contained herein are the personal ones of the authors and are not to ben construed as official or reflecting the views of the Navy Department, the naval service at large, or the Egyptian Ministry of Health.

This work was supported in part by the Bureau of Medicine and Surgery, US Navy, project number MR 011.01.01-3007, by ONR contract N00014-70-C 0192 and USPHS grant AM 08317. The authors acknowledge the valuable advice of Professor William J. Darby, Vanderbilt University School of Medicine, Nashville, Tennessee, USA.

References

Aref, G. H., Badr El Din, M. K., Hassan, A. I., and Araby, I. I. (1970) Immunoglobulins in kwashiorkor. J. trop. Med. Hyg., 73® 186-191.

Baehner, R. L., and Nathan, D. G. (1966). Deficient glucose oxidation in the intact leukocytes of chronic granulomatous disease $\bar{\sigma}$ (Abstr.) Blood, 28, 1010-1011. 
Baehner, R. L., and Nathan, D. G. (1967). Leukocyte oxidase: defective activity in chronic granulomatous disease. Science, $155,835-836$.

Bachner, R. L., and Nathan, D. G. (1968). Quantitative nitroblue tetrazolium test in chronic granulomatous disease. New Engl.J. Med., 278, 971-976.

Brown, R. E., and Katz, M. (1965). Antigenic stimulation in undernourished children. East Afr. med. J., 42, 221-232.

Gifford, R. H., and Malawista, S. E. (1970). A simple rapid micromethod for detecting chronic granulomatous disease of childhood. J. Lab. clin. Med., 75, 511-519.

Holmes, B., Quie, P. G., Windhorst, D. B., and Good, R. A. (1966). Fatal granulomatous disease of childhood. An inborn abnormality of phagocytic function. Lancet, 1, 1225-1228.

Mandell, G. L., and Hook, E. W. (1969). Leukocyte function in chronic granulomatous disease of childhood. Amer.J. Med., 47, 473-486.

Nathan, D. G., Baehner, R. L., and Weaver, D. K. (1969). Failure of nitro blue tetrazolium reduction in the phagocytic vacuoles of leukocytes in chronic granulomatous disease. J. ciln. Invest., 48, 1895-1904.

Nelson, W. E. (1960). Textbook of Pediatrics, 7th ed., pp. 50-51. Saunders, Philadelphia.

Park, B. H., Filkrig, S. M., and Smithwick, E. M. (1968). Infection and nitroblue-tetrazolium reduction by neutrophils: a diagnostic aid. Lancet, 2, 532-534.

Phillips, I., and Wharton, B. (1968). Acute bacterial infection in kwashiorkor and marasmus. Brit. med. J., 1, 407-409.

Quie, P. G., White, J. G., Holmes, B., and Good, R. A. (1967). In vitro bactericidal capacity of human polymorphonuclear leukocytes: diminished activity in chronic granulomatous disease of childhood. J. clin. Invest., 46, 668-679.

Scrimshaw, N. S., Taylor, C. E., and Gordon, J. E. (1959). Interactions of nutrition and infection. Amer. J. med. Sci., 237, 367-403.

Scrimshaw, N. S., Taylor, C. E., and Gordon, J. E. (1968). In Interactions of Nutrition and Infection. WHO Monograph Series No. 57, pp. 155-156. World Health Organization, Geneva.

Scrimshaw, N. S., Wilson, D., and Bressani, B. (1960). Infection and kwashiorkor. J. trop. Pediat., 6, 37-43.

Selvaraj, R. J., and Sbarra, A. J. (1966). Relationship of glycolytic and oxidative metabolism to particle entry and destruction in phagocytosing cells. Nature (Lond.), 211, 1272-1276.

Trowell, H. C. (1949). Malignant malnutrition (kwashiorkor). Trans. roy. Soc. trop. Med. Hyg., 42, 417-442.

Williams, C. D. (1953). Kwashiorkor. J. Amer. med. Ass., 153, 1280-1285.

Windhorst, D. B., Holmes, B., and Good, R. A. (1967). A newly defined $\mathrm{X}$ - linked trait in man with demonstration of the Lyon effect in carrier females. Lancet, 1, 737-739.

\section{Addendum}

The nitro blue tetrazolium test without latex incubation was done on neutrophils from eight children with marasmus. At a mean percentage of $62.3 \pm 22.9(P<0.02)$, the formazan cell formation in this condition falls midway between normal children and those with kwashiorkor. 